$$
\frac{27}{11-28 \cdot 80}
$$

\title{
Compression and Extension Data for Dome Salt from West Hackberry, Louisiana
}

Wolfgang R. Wawersik, David W. Hannum, Hank S. Lauson

\section{(7) Sandia National Laboratories.}


SAND79-0668

Unlimited Release

\author{
Compresaion and Extension Data for Dome Selt From \\ West Hackberry, Loulsiana
}
W. B. Wewersik, L, 7 . Hennum and $F . s$. Lauson
Sende tational Iaboratoriea
Albuquerque, New Mexico $(71$ b)

\begin{abstract}
Abstrect
Results of six quesi-static test and four creep experiments are described in terms of standerd quasi-static mat"rial properties such as untaxial compressive strength, strain-to-failure, secent moduli, etc., and in terms of wa kncwn creep formulations. The creep formulations consiat of a combined primary/secondary creep model and a purely transient creep model. AIJ results are compared with published data for rock salt from the Jefferson Island lome and for bedded salt from the Wellington and Salado formations. They are consistent with results from these three siles sugge日ting that West Hackberry rock galt can be described by means of congtitutive relations which are now available or currently under development. Comparative data for triaxial empresston and triaxtel extension also 1adicate thet these adeis can be epplied to predict the shear deformation of rock salt under generai stress states but that modifleations wight be needed to predict rock salt Eracture.
\end{abstract}

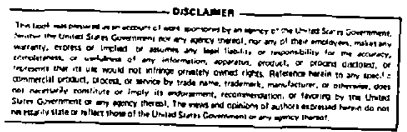




\section{Table of Contents}

List of Symbols and Conventions........................... 111

List of Tobles $\ldots \ldots \ldots \ldots \ldots \ldots \ldots \ldots \ldots+\ldots \ldots \ldots \ldots \ldots \ldots \ldots$

List of figures $\ldots \ldots \ldots \ldots \ldots \ldots \ldots \ldots \ldots \ldots \ldots \ldots \ldots \ldots \ldots$

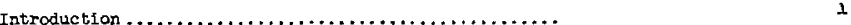

Source of Matertal and 3emple lescription ........... 2

Apeark tus and Experinenial Brocedures .............

Test fatrlx $\ldots \ldots \ldots \ldots \ldots \ldots \ldots \ldots \ldots \ldots \ldots \ldots \ldots \ldots \ldots \ldots$

Experimental Results ........................

Quesi-Stetic Tests .....................

Creep sxperiments ....................... 11

Discussion $\ldots \ldots \ldots \ldots \ldots \ldots \ldots \ldots \ldots \ldots \ldots \ldots \ldots \ldots \ldots \ldots \ldots \ldots$

Sumery and Conelusions $\ldots \ldots \ldots \ldots \ldots \ldots \ldots \ldots \ldots \ldots \ldots \ldots$

References $\ldots \ldots \ldots \ldots \ldots \ldots \ldots \ldots \ldots \ldots \ldots \ldots \ldots \ldots \ldots \ldots \ldots$

Figures $\ldots \ldots \ldots \ldots \ldots \ldots \ldots \ldots \ldots \ldots \ldots \ldots \ldots \ldots \ldots \ldots \ldots \ldots \ldots$ 


\section{Ligt of Symbols and Conventions}

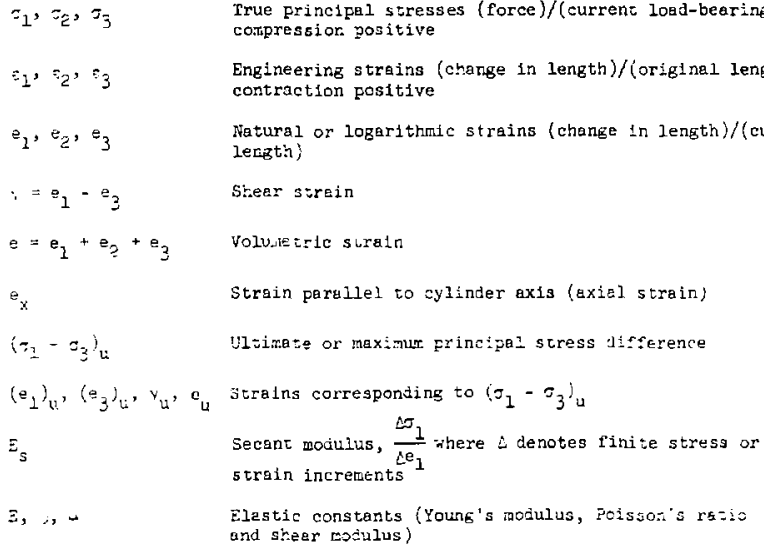




\section{Iist of Tables}

Table I: Chemical and Dissolutioning Data

Table II: Teat Matrix

Table III: Kaximum Stresees and strains of quasi-Stalic Tests

Table NV: Suncary of Deformation Characteristies of West Hackberry jant Salt Upon First Laberstory Loaine and List of Elsst1e Coaster:a

Tajle V: Surnary of Date of Creep Euperiments

Table VI; Fitting Parameters for Axial Creep Straina, $e_{x}$.

Table VII: Indicator Tropertlea for Rock 5alt Frow West Hackberry, Jeffersor. Ialand, arci Lyong 


\section{Liat of Figures}

Flesure 1: sap of 2000 It (625 n) contour of West Hackberry dope. Cross hatched boundary defines DOE property line.

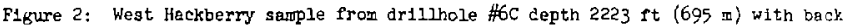
lliumination.

Figure 3: Trigxiel test apparatus.

F1gure 4: Fxtension speciren in flexible Vitor jecket with two disix gauges and transfer buttons.

Figure 5: Principal stress difference Y日, axtal strain 1n unconflned compression tests at 22 and $60^{\circ} \mathrm{C}$.

Figure 6: Fincipel atreas difference vs. ahear straln for uniexial gad triaxial compreseion tests $\left(\sigma_{2}=c_{3}\right)$ at 22 and $60^{\circ} \mathrm{C}$.

Figure 7: Princlpal atress difference vs. volumetric straing for uniexial and triaxial compression teats $\left(\sigma_{2}=\sigma_{3}\right)$ at 22 and $60^{\circ} \mathrm{C}$.

Pigure 8: Comparison or triaxial compregsion and triaxial extension deta in the apace $\left(\sigma_{1}-\sigma_{3}\right)$ vs $Y=\left(e_{1}-\xi_{3}\right)$ at 22 and $60^{\circ} \mathrm{C}$.

Figure 9: Comparison of triaxial compession and triexial extension jata in: ibe space $\left(\sigma_{1}-\sigma_{3}\right)$ rs e et 22 and $60^{\circ} \mathrm{C}$.

Figure +O: Compariaon of triaxial compression and triexinl extension data in the space $\gamma=\left(e_{1}-e_{3}\right)$ vs e at 22 and 6000 .

Figure 11: Shear creep in triaxial compreasion and triexial extension at 22 anci $60^{\circ} \mathrm{C}$.

Figure 12: Volumetric creep in triaxial compresalon and triaxial exteneion at 22 and EOOC.

Figure 13: Compertaon of shear creep based on independent messurements of radial sample defornations.

Figure 14: Comparison of volumetric creep baged on independent pegeurements of railal sample deformationa. Noise in diletoretric reccrds is due to therwally induced volume changes of confining pressure mediun.

Flsure 15: Comperison of extal creep data, e, vs, t for dome aglt from West Hackberry and Jefferson Island, Loulsiana and for bedded salt from Wellington formation, Lyons, Kansas.

Flgore 16: Comparison of secondary (ateady state) creep retea for ifest hackberry dome salt with bedded salt from the Salado formation, southeastern lew Mexico. 


\section{Inzroduction}

The work in this report was part of a short-term systems und engineerlng study to suppert the U.S. Strategic Petroleun Reserve (SPR) Program, Guaststatic and creep tests were consusted to old a fint:e element s ouid ot the stesility of an existing oil storage cavern, cavern $\#$ in the Hest Hackberry : ome, West fackbarry, Louisiana, The top of the cavern is located at a depth of $3250 \mathrm{ft}(950 \mathrm{a})$. The cavern is approximalely $150 \mathrm{ft}$ (46 m) high ant עotweer $334 \mathrm{ft}$ (10e a) anc $420 \mathrm{f \tau}(128 \mathrm{~m})$ in tiameter. Calculazions were partlcularly concerned with predicted creep alosure of the cavern os a result of caveru depressurization from 1725 psi (11.g VPa) to 1145 psi

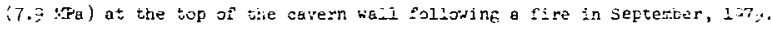
Jeceuse nc site-spezig:z dote were aveileble e: jre jeginnine of tisis studg, all calculations were performed by means of existing material froperties for rock salt from the Jefferson Island dome, Louisiana and from the bejted deposits of the Wellington formation at Lvons, kensas. ${ }^{1}$ The presert data provije the first site-specific properties anc serve to evaluaze the applisabilizy of Jefferson Island and Lyons results to West Heckberry conattions. They also pesit a check of three sess of essuptions which were cade in tice stractural calculations under this progras: (1) Creep as less trar approxirately oc days, including the time for dissolutioning, is limited to transient (deceleratine) oreep which can be desoribe: by geans of an equatior. of the rorc:

$$
\left.e_{1}=s_{1}-z_{3}\right)^{m} t^{n}
$$

Where $\epsilon_{1}$ ens $=$ are the Ereacest compressive sirain and tize. $\left(z_{1}-z_{3}\right.$ is the principal stress difference. (2) Sreep procedas wi th no crante in aterial 
yolure, 1.e., creep data fron triaxisl compression testa can be ured in lleu of creep data in triaxial exuension which best cescribes the loading conditions In the walls of oil storage caverns; and (3) Temperature effects to approximately $60^{\circ} \mathrm{C}$ are subordinete.

Ten experiments were conducted at zero and $2000 \mathrm{pgi}$ (13.8 MF) confining pressure and at $22^{\circ} \mathrm{C}$ temperature. Two tests at $\sigma_{3}=2000 \mathrm{psi}$ (13.8 MFa) were csrried out in triarial compression $\left(\sigma_{2}=\sigma_{3}\right)$ and two in triexial extension $\left(s_{2}=\sigma_{1}\right)$. Creep of West Hackberry salt was moni tored in four tests up to 475 hours at a nominal principal stress difference of $\left(\sigma_{1}-a_{3}\right)=3000$ ps 1 (21 $\mathrm{MPa}$ ).

\section{Source of Material and Semple Description}

The West Hackberry dome is Located in Caneros parish in southwestern Lousiana. It is an elliptical piercement structure of Jurassic salt into eocene sediments. ${ }^{2}$ The dome $1 s$ part of a larger salt mass which is approximately $8.7 \mathrm{miles}(14 \mathrm{~km})$ long and at least $1.9 \mathrm{miles}(3 \mathrm{~km})$ wide. The top of the dome is nearly flat and located at approximately $2000 \mathrm{ft}$ (625 a) belor surface under up to $525 \mathrm{ft}$ (164 a) or cap rock. The flanks of the doce dip fron slightly less than $60^{\circ}$ to more than $75^{\circ}$ in the north. Core tested vas tiken from two drillholes, 46 and \#8h into the ceverne $\# 6$ and $\# 8$. Hole $\$ 6 \mathrm{C} 1 \mathrm{~s}$ located $300-500 \mathrm{ft}(100-150 \mathrm{~m})$ from the northern edge of the top of the dome. Hole \#BA is located more thar 1000 ft $(300 \mathrm{~m})$ to the soutb of hole $\# 6 \mathrm{c}$. Soth holes ere itentifled in Figure 1 relative to the $2000 \mathrm{ft}(625 \mathrm{a})$ contour of the dore.

Core tested was taken rror depths $2200-2242$ ft $(671-684$ a) in hole $46 \mathrm{C}$ eni from 2300-2303 ft (701-702 r) in hole \#8A. Compositions were deterained on three hand apectuens which appeared to he typical for the darkegt least 


\section{Table I}

Chemical und Dissolut: orirg Data ${ }^{\text {(3) }}$

Weight \%

$$
\text { F } \text { ive }^{+}
$$$$
\mathrm{x}^{+}
$$

$\% \mathrm{Ca}^{+}$

$\% \mathrm{HB}^{++}$

$\% \mathrm{Cl}^{-}$

$\mathrm{gos}_{4}^{=}$

क $\mathrm{CO}_{3}=$

$8 \mathrm{HCO}_{3}$

in ingoluble Residue

wt. of Sample (gras.)

Notes:
Sample I.D. (Hole No.-Depth, ft. L (Saraple Fraction)

6C-2208(1) 60-2208(2) EC-22L1

$$
37.7
$$

36.5

37.5

0.001

0.001

2.61

0.272

0.360

0.271

$<0.0001$

$<0.0001$

$<0.0001$

58.5

57.4

55.5

0.65

0.06

0.00

$\leq 0.005$

$\leq 0.005$

$<0.005$

$\leq 0.025$

$\leq 0.005$

$\leq 3.205$

1.37

3.70

a. $5 \mathrm{~L}$

$\Rightarrow 100$

$\approx 100$

$\Leftrightarrow 100$

Most transparent
Jarkest, visue.1ly leest pure
Mix of trensperent gna Jark 5elt: 
pure and for the sost transparent clean material. ${ }^{3}$ X-ray analyses 1dentified only sodium chloride and anhydrite $\left(\mathrm{CaSO}_{4}\right)$. The results of chemickl analyses are summarized in Table $I$. Table I suggests that all rock salt consisted of more than $93 \% \mathrm{NaCl}$. Considering the brine concentrations used and the stability or antydrite, ${ }^{4}$ it can aiso be assured that the total anhydrite content varied between $2.7 \%$ and $5.3 \%$. The anhydrite shom occurred primarlily in steeply dipping bands in core from drillhole \#6c. The width of these bands varied from 1.2 in $(1.5 \mathrm{~cm})$ to more than 4 in $(10 \mathrm{~cm})$. Core $\$ 60$ also containec elongated graing with greatest dirensions between 0.24 in $(6 \mathrm{~m}$ ) ard $1.2 \mathrm{in}(30 \mathrm{~mm})$ and wich ispect retios from 1.5 to 3.5 . The Long axes of these grains lay approxinately parallel to the anhydrite rich bands. The grain boundartes were reletively smooth indicating a moderate legree of grain interlocking. A typical semple from drizhole $46 \mathrm{C}$, which wes illuminated from behind, is shown in Figure 2 .

Contrary to care frow hole \#6c, the grains in core frop drillhole \#BA were approximately equiaxed. They showed no preferred arlentation. The grain size veried fror 0.16 in to 1.2 in $(4-30 \mathrm{~mm})$. Specimen $8 \mathrm{~A}-\tilde{z} 30$ included several large euhedral grains.

\section{Apparatus anc Experimentel Procedure日}

Tests were perfomed in twc identical triuxial apparatus gapable of accommoating specimens up to 4 in $(10.8 \mathrm{~cm})$ in diameter and 8.25 in (21 cm) in length. Figure 3 is a photograph of the equipment.

Prior . testing, a.1 specinens were svered with a 0.01-0.02 in (0.25-0.5 t: : $: k$ layer of RTV sllestic (RTY 108) for protection agalnst the effects of huridity and to fill small surface pits or holes. This procedure is facilitated if the RTV is first thinned with toluene. Arter ccating, each sarple is placed between two steel end-caps and enclosed in an 
elestocer jecket of Viton, liecpreze or EFDs. Thi. well thickness of these fackeis is approximetely 0.66 in $(1.5 \mathrm{mr}$ ). To ensure gooi alignment, all specimen ends are machised flac and parallel to $\pm 0.001 \mathrm{ir}$. ( $40.005 \mathrm{~mm})$. End effects at the interface batween rook salt and end-capy are cinimized by polishing the end-cap faces to a mirror finisi and by conting the sample ends with thin layers of moloycerlum disulfice (Molykote). All tests were started from a state or hydrostatic compression egual to the

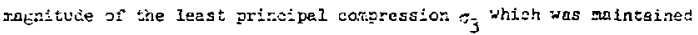
constant.

Deviator stress was generated hy incressing the axial specimens stress in triaxial compression and by increasint; the radial pressure $\sigma_{2}=r_{1}$ in iriexiel extension.

Axial specimen strains were monitorei by ceans of LVDT (Lineur Yarkakte iifferential Treasformer) transducers parallel to the sample axes. Radial strains Here measured dilatometricalizy andor by means of two disc gauges. The placement of these disc pauges is demonstrated in Figure 4 . Setrìs of both techniques, calibration procedures and ifte rejuction nethols are discussed elsewhere. 5

Quesi-static tests ware perfored at a mean jeviatoric stress rate of $1 \leq \frac{\dot{d}}{\dot{\mathrm{t}}}\left(\sigma_{1}-\mathrm{J}_{3}\right) \leq 2 \mathrm{psi} / \mathrm{a}(7$ to $\mathrm{i} \mathrm{K} \mathrm{za} / \mathrm{s})$. This rate was approacted in incremental fashion by quick, almost instantaneous shanges in ram load followed by periots of several minutes durting which the logd was held fixed. Variations is. the ssress rate were cacsed by changes in the specimen area with chrnges in radial sample strairs. Creep wes intiatec by rapid deviatoric loading in triaxial compression, d/dt $\left(e_{1}-3_{3}\right) \approx 75$ psis $(500 \mathrm{kPa} / \mathrm{s})$. The creep stress was reached at a slibhtly lower rete $\frac{d}{d t}$ $\left(s_{1}-c_{3}\right) \approx 22 \mathrm{psi} / \mathrm{s}(150 \mathrm{kPa} / \mathrm{s})$ in triexial extension. 
Test Matrix

Table II shows the ten experiments desoribad in this report. The test 1lentioication (I.D.) In the first column 1a used in subsequent rigures and designates the following: (nominal core dlaneter, in) (:dentifiention of test type)/(driwhole \#)-(depth, t't)/(least compressive stress, $k s i) /\left(\right.$ tect temperature, ${ }^{\circ} \mathrm{C}$ ). The abbreyiated code for test type intifies four different experiments. Q: quasi-static compression test, ï: quesi-ctatic extension test, C: triaxial conpression creop test an.

F: triaribl nxtersion creep experiment. Based on elastio compulation.:

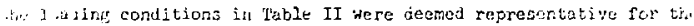

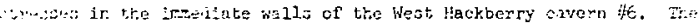

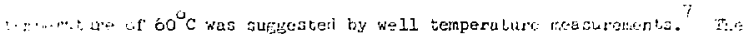
valuer fur yrincipal streas jifference and heasi conpressive atreaz for îur nroeg experipents cre sverages for the curation of each teit.

Ran core of 4 in ( $10.8 \mathrm{cn}$ ) diameter was used for convenience in four of the guasi-sbatic corpressior tests. Sagples or 3.5 1n. (8.9 ca) Jiateter nere irilled for the remainder of the experiments primarily because of ccnstraints of the available apparatus in the mode of triaxlal extension.

\section{ixperimental Results}

\section{Quasi-Static Tegus}

The quasi-atatio data obtained are presented in Figures 5 through 10 using conveitional graphs of principal stress difference, $\left(\sigma_{1}-\sigma_{3}\right)$, yeraus greatest compressive stra1n, $e_{I}$, as well as cross plots of $\left(\sigma_{1}-\sigma_{3}\right), y, e$ and timc. $e_{I}, e_{3}, \gamma$ and $e$ are natural strains. Denoting compressive strains positive the natural strains are obtalned frog measured dimensional changes and engineering atrains ${ }^{2}{ }_{1} e_{3}$ as 


\section{Table II}

\section{Test Matrix}

Test I.D.

$4 Q / 6 \mathrm{C} 2206 / 0 / 22$

$4 Q / 8 \mathrm{~A}-2302 / 0 / 60$

$4 Q / 8 A-23.02 / 2.0 / 22$

$4 Q / 6 C-2208 / 2.0 / 60$

$3.54 \mathrm{E} / \mathrm{OC}-224 \mathrm{~A} / 2.0 / 22$

$3.5 Q 1 / 6 \mathrm{C}-c^{2} ? 23 / 2.0 / 60$

$3.50 ; 6 \mathrm{c}-2241 \% .0 / 22$

$3.5 \mathrm{C} / 6 \mathrm{C}-2201 / \% .0 / 60$

$3.5 \mathrm{CE} / 6 \mathrm{C}-2225 / 2.0 / 2.2$

$3.5 C E / 6 C-27-94 / 2.0 / 60$

\section{Descrintion of Test}

Unconfined quasi-static coapression, $\sigma_{3}=0, T=22^{\circ} \mathrm{C}$

Unconfined qunsi-atatic compresston, $\sigma_{3}=0, T=60^{\circ} \mathrm{C}$

quasi-gtatic triaxial compression, $\tau_{2}=\sigma_{3}=2000$ psi, $\mathrm{T}-22^{\circ} \mathrm{C}$

Quasi-stutic triaxial compression, $\sigma_{2}: \sigma_{3}=2000 \mathrm{psi}, \mathrm{T}: 60^{\circ} \mathrm{C}$

Quesi-static triuxial extension, $\sigma_{2}=\sigma_{1}=2000$ psi, $\mathrm{T}=22^{\circ} \mathrm{C}$

Quasi-stat1c triaxial extension, $\sigma_{2}=\sigma_{1}=2002 \mathrm{psi}, \mathrm{T}=60^{\circ} \mathrm{C}$

Triaxia) ampression creep, $\sigma_{2}=\sigma_{3}=2$ s0 psi, $\left(\sigma_{1}-\sigma_{3}\right)=2$ אо psi,

$$
\mathrm{T}=22^{2} \mathrm{c}
$$

Triexie1 compression creep, $\sigma_{2}=z_{1}=2030 \mathrm{psi},\left(\sigma_{1}-z_{3}{ }^{\prime}=2900\right.$ ps1,

$$
\mathrm{T}=60^{\circ} \mathrm{C}
$$

Triexial extension creep, $z_{2}=z_{1}-1900$ pit, $\left(\sigma_{1}-\tau_{3}\right)=2900$ psi,

$$
I=22^{\circ} \mathrm{C}
$$

Triexial extension creep, $z_{2}=z_{1}=270$ psi $\left(z_{1}-z_{j}\right.$. 2090 psi,

$$
\mathrm{T}=60^{\circ} \mathrm{C}
$$




\section{Table III}

Maximun itresses and Straine of Quasi-Static Tests. Subscript u Partains to Ultimate jtress and Strain values.

\begin{tabular}{|c|c|c|c|c|c|c|c|}
\hline & $\begin{array}{c}0_{3} \\
\text { (psi) } \\
\end{array}$ & $\begin{array}{l}\left(o_{1}-v_{3}\right)_{21} \\
\text { (ns } 1)\end{array}$ & $\begin{array}{l}\left(e_{2}\right)_{u} \\
\langle b\rangle \\
\end{array}$ & $\begin{array}{c}\left.-e_{3}\right)_{u} \\
(\phi) \\
\end{array}$ & $\begin{array}{l}(p) u \\
(y)\end{array}$ & $\begin{array}{l}\text { (E) } \mathbf{u} \\
(t)\end{array}$ & $\begin{array}{l}(-)^{*} \\
(j)\end{array}$ \\
\hline $10 / 6 \mathrm{c}-2206 / 0 / 22$ & 0 & 3790 & 2.5 & 4.0 & 6.5 & -5.5 & - \\
\hline $140 / 8 A-2302 / 0 / 60$ & 0 & 3540 & 5.0 & 5.9 & 10.9 & -6.8 & -5.5 \\
\hline $4 Q / 8 A-2301 / 2.0 / 22$ & 2000 & $>8570$ & $>24 \cdot 3$ & $>8.3$ & $>22.6$ & -2.3 & $-2,4$ \\
\hline $40 / 6 \mathrm{c}-2208 / 2.0 / 60$ & 2000 & $>7540$ & $>25.4$ & .14 .1 & $>39.5$ & -2.9 & -3.9 \\
\hline $3.50 \mathrm{Q} / 6 \mathrm{c}-224 \mathrm{~L} / 2.0 / 22$ & 2000 & $>6740$ & $>3.5$ & $>6.0$ & $>9.5$ & 1.0 & 0.4 \\
\hline $3.5 \mathrm{QE} / 6 \mathrm{c}-2223 / 2.5_{6} 6$ & 2000 & $>5050$ & $>3.8$ & $\therefore 6.4$ & $>10.2$ & 1.2 & -0.1 \\
\hline
\end{tabular}

\footnotetext{
Total rolumetric strala estimates besed on selected meaguerents of finf opecimen dicnengions.
} 
Tuble: TV

Sunary of Deformation Characteristies of West Hackberry Dome Sult Jpon First Laboratory Loading and List of GLaslic Constants

\begin{tabular}{|c|c|c|c|}
\hline Test I.D. & 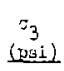 & $\begin{array}{c}\text { Frcan } \text {, oculus }\left(10^{\circ} \mathrm{psi}\right) \\
200 \leq 0(\mathrm{psi}) \leq 1000\end{array}$ & $\begin{array}{l}\text { /Prine. Strain futio } \\
500 \leq L(\operatorname{pg} 1)<2000\end{array}$ \\
\hline $4 a / 6 c-220 \sigma / 0 / 22$ & 0 & $0.22 /-0.30$ & $0.68 /-0.68$ \\
\hline $42 / 8 A-2302 / 0 / 60$ & 0 & $.16 /-0.56$ & $0.32 /-0.71$ \\
\hline $40 / 8 \mathrm{~A}-2301 / 2.0 / 22$ & 2000 & $1.75 /-0.63$ & $0.90 /-0.52$ \\
\hline $40 / 6 \mathrm{c}-22 \mathrm{c} 8 / 2.0 / 60$ & 2000 & $1.83 /-0.30$ & $1.05 /-0.37$ \\
\hline
\end{tabular}

$$
\begin{gathered}
\begin{array}{c}
\text { Elustio (unloaling) } \\
\text { Copstant: } \\
\mathrm{E}\left(10^{\circ} \mathrm{psi}\right) / \mathrm{v}
\end{array} \\
\begin{array}{c}
(3.7 / 0.65)^{*} \\
(5.6 /-)^{*}
\end{array} \\
5.55^{+0.06}-0.22 / 0.33+0.02 \\
5.67 \begin{array}{l}
+0.25 \\
-0.20
\end{array} / 0.31 \pm 0.3
\end{gathered}
$$

* Megsurement made past the ultimate stress. 


$$
\begin{aligned}
& e_{1}=-\ln \left(1-\left|c_{1}\right|\right) \\
& e_{3}=-\ln \left(1+\left|c_{3}\right|\right) \\
& y=e_{1}-e_{3} \\
& e=e_{1}+e_{2}+e_{3}
\end{aligned}
$$

$e$ and $v$ ere volumetric and shear strains, respectively.

Eigure 5 affcrdg a comparison of the unconfined behavior of Hes: Hackberry material at $22^{\circ} \mathrm{C}$ and $60^{\circ} \mathrm{C}$. The steps $1 \mathrm{n}$ the two stress strain curses are results of the incrementel deviatorle loading procodure described earlier. In subaequent plots steppej stress-straln eurves sonetires are epproximated by snooth curves which were drawn trrough the end polats of each step, e.g., points $A$ and $B$ in Figure 5. It 1g noteô that plots or princ1pal stress difference versus obear strain and volumetric strain are the most eppropriate repreaentations to compere the results or triaxial compression and triaxial extension tests (Figures 8 through 10 ).

Further inspection of Floures 5 throwgh 10 provides the supplementary data in Rables III and IV. il III lists the unconfined strengths and the associated ultinete strains. Table III, column 3, also conteins the naximum streases below the ultimgte stresses which were reached at elevated values of $\sigma_{3}$. It $1 \mathrm{~s}$ noted that the ultimete stresses were not reached at $\sigma_{3}=$ 2000 ps: (13.8 MPu) and greatest compression strains $e_{1} \leq 25.4 \%$ because the deviator stresses were gt:17 increesing when these cxperiments were termineted. However, observations of dilatency ${ }^{*}$ (Flgure 7) imply that fracture would have developed if the exper1mepts had been cont1nued.

*iletancy denotes increased in rods volume reletive to purely elastic volume changes with changeg in mear stress. 
In view of the ducille nature or rock salt, the non-zero volumetrit strain values which were xonttored In triaxial complession and trlaxial extension must be considered sugpect in principle. To mintmize the ursertainty concerning the validity of these results, volumetric strains were

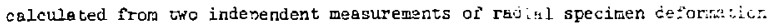
using dilatometric and dise gauge readings. These two sets of data are essentially identical. Additionally, the volumetric strains which were determines fron records of axial and radial sample deformation were compars: with volumetrlc straln estimates tasei on measureceric of the final semple dimensiors after teating. The letter values were entered in the last coiumn of Table III. They constitute relatively crude eatloutes because of local grain bulging. ilitis the exception of sample 6c-22ç, tice trent of tre jate in column? and 8 is consistent although the quantitative agreement is pror.

Table IV containg the values of secent modult and principal sirsin ratios which describe the response of West Heckberry salt upon first laboratory loeding. Such values are used frequently to evaluate tine behavior of rock salt from different sites. They also indicate the non-elastic nature of this material. The elastic properties of hest Hackoerry sali were established in rapid urloading tests at st.esses below approximazeij $60 \%$ of the previously attalned peak stress when time dependent deformstion tecones subordinate.

\section{Creep Experizents}

The results of the four sreep experlinents are sumarized in Tabies $V$ and VI aid in Figures 17 and 12. Variations in the initial logdre rates (colum 6 of Table v) were unintentional and Nere primarily due to restrictions in the flow rate through hydraulic ines and in the output capacity of one of the pressure sources. In spite of these restrictions, 
Table V

Sumary of Data of Creep Experiments

\begin{tabular}{|c|c|c|c|c|c|c|c|}
\hline Test 1.0. & $\begin{array}{l}\left.1-\sigma_{3}\right) \\
(\mathrm{ps} i) \\
\end{array}$ & 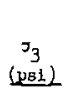 & $\begin{array}{l}\text { Initial } \\
\text { Loading } \\
\text { Rate } \\
\text { (ps1/s) }\end{array}$ & $\begin{array}{c}\text { Test } \\
\text { Duration } \\
\text { (brs) } \\
\end{array}$ & $\begin{array}{r}\text { Intia } \\
e_{1} \\
\end{array}$ & $\begin{array}{l}\text { Strains } \\
-\mathrm{c}_{3} \\
\end{array}$ & $\begin{array}{c}\text { llin. Observed } \\
\text { Axial Creep Rate } \\
\text { es }\end{array}$ \\
\hline $3.5 c / 6 c-2243 / 2.0 / 22$ & 2966 & 2030 & $; 2.2$ & 475 & .52 & 0.21 & $9.470-9$ \\
\hline $3.5 \mathrm{C} / 6 \mathrm{C}-2201 / 20 / 60$ & 2900 & 2030 & 95.7 & 263 & .69 & 0.27 & $7.23 \mathrm{E}-8$ \\
\hline $3.5 \mathrm{CE} / 6 \mathrm{C}-2225 / 2.0 / 22$ & 2900 & 1990 & 30.5 & 262 & 0.13 & 0.18 & $1.19 \mathrm{E}-8$ \\
\hline $3.5 \mathrm{CE} / 6 \mathrm{C}-2196 / 2.0 / 60$ & 2890 & 2070 & 14.5 & $72^{*}$ & 0.25 & 0.37 & ל. YTE-ij \\
\hline
\end{tabular}

*Teat ran to 327 hrs; however, loading piston tottoned out arter $T 2$ hrs renderinf eubsequent data invalid. 


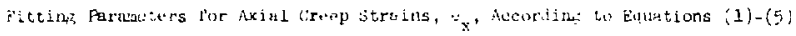

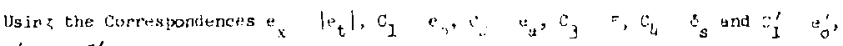

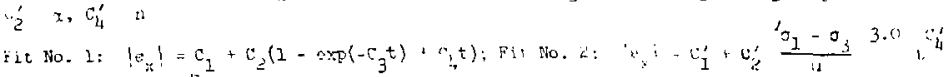

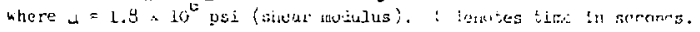

\begin{tabular}{|c|c|c|c|c|c|c|c|}
\hline \multirow{2}{*}{ 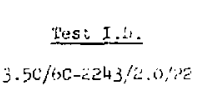 } & \multirow{2}{*}{ 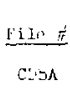 } & \multirow{2}{*}{$\begin{array}{l}\text { Ni: } \\
\text { No: }\end{array}$} & \multicolumn{4}{|c|}{ Subscript of consunts } & \multirow{2}{*}{ 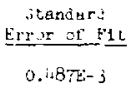 } \\
\hline & & & \pm & \multicolumn{3}{|c|}{$1 . x+-2 \quad 0+\cdots b-1 \quad 1.32 E-i$} & \\
\hline & & $\cdot$ & 3. $-4+x-1$ & $1.515-3$ & $\therefore \ldots$ & $\therefore .33$ & $394 \mathrm{E}-2$ \\
\hline $3.506 / 60-228512.0 / 2$ & $\because \because k$ & $?$ & $\therefore .33 E-3$ & $+36 x=$ & A...bs:- & 1.1汪-" & $i .6325-j$ \\
\hline & & . & 1.... & . 织 & 29 & $2.3+3$ & $.225 \mathrm{E}-2$ \\
\hline $3 / 50 / 6 \mathrm{C}-2201 / 2.0100$ & DIOA & 1 & $4,(2)-3$ & $\therefore$ 口过- & $3 O E-5$ & $3.93 \mathrm{E}-0$ & $230 E-2$ \\
\hline & & $\therefore$ & $1.05 \mathrm{E}-2$ & 4. $.9 \pm 3$ & 3.20 & 0.609 & $.173 \mathrm{E}-2$ \\
\hline $3.5 \mathrm{CE} / 6 \mathrm{C}-2196 / 2.0 / 60$ & $\therefore 7 k$ & 1 & r.々E⿺廴 & $\therefore .32 \cdot E-2=$ & $5595-5$ & $1.30 \ddot{r}-7$ & $.128 \mathrm{E}-2$ \\
\hline & & & $\therefore .2 H_{1} E-3$ & $\left.\because v^{2}\right) \mathrm{E}^{2}$ & i. . . & 0.401 & $a, 236 \mathrm{E}-3$ \\
\hline
\end{tabular}


the intial loading rates were 14 to 94 times greater than the mean Ioading rate In all quasi-static tests. Nevertheless, the ration of the data in colums 2 and 6 in table $v, 1 . e$. , the atreas differencea divided by tr. Inltial loading strains which are equal to the secant moduld $\mathbf{E}_{8}$, atill fal: 1nto the relatively low range $4.4 \times 10^{5} \leq \mathrm{z}$ (psi) $\leq 2.3 \times 10^{6}$ ( 3.0 to $16.1 \mathrm{GPa}$ ) and are well below the intrinsic elnstic godulus $E \div 5.6 x$ $10^{6}$ (39 GPa) (Table IV).

Figures 21 and 22 are plots of the measured shear stralas and volumetric streins versus tise. The cusp in the creep curve for semple $6 \mathrm{c}-2201$ (Flg. 11) is jue to a gradual, 190 psi (1.3 (Ma) stress drop between the 25 th and 70th hour of testing when the stress was updated. This stress arop was caused by considerable changy in specimen area at constant applied force. Azain, the observed rolumetric strains are suspect, but no nessurement errors coult be identifled. Increased dilatancy with an Increase in temperature in the compression test in Fig. 12 is unexpected. However, this dilacancy was assoclated with greater shear strains than developed at $22^{\circ} \mathrm{C}$. It gny also be that the differences tetween results at arbient and elevated temperature are due to compositional and textural variations between samples. The indicated corpaction in Fig. 22 for extension tests was computed Indefendentiy by means of fndlrect and by cirect measurements of radial specimen ceformations. A grephical comparison of the two sets of measurements is shown 1 f Flgures 13 and 14 for samples 6C-2201 and 6c- $2 \hat{c}+3$, Ordinarily, the dllatometric procedure to conitor radial jeformetions provides the lowest volumetric stra1n values. Interpretation of the creep date followed two approsches. First, all measurements of total creep strain, e were fitted to a combined primary/ seconciary sreep model of the form 


$$
\left|e_{t}\right|=e_{0}+e_{p}+\dot{e}_{t} t
$$

where

$$
e_{p}=e_{e}\left(1-e^{-j t}\right)
$$

Here the total natural strain $e_{t}$ is taken to be the axibl specimen strein $e_{x} \cdot E_{2}$ is a saturatior value, $e_{s}$ 1s the secordary creep rate, anc is a relaxation frequency. Time is expregsed in secunds. Accuraing to (k), reaches scme fraction, $f$ of $e_{a}$ when

$$
t=-\frac{\ln (1-r)}{\vdots}
$$

The choice of fit to Equatsons (1) and (2) is besed on the analysis of a lare number of results for bedled rock salt from the Saledo formetion in sod:heasterc Mew Hexico, 8,9

The second type of fit was of ten applled to the interpretation of wodel pillar tests and, later, to rock salt creep et constant stress: ${ }^{10-14}$

$$
\left|e_{z}\right|=e_{0}^{\prime}+ \pm t^{n}
$$

where $e_{t}=e_{x}$ end

$$
I=\bar{s}\left(\frac{a_{1}-a_{3}}{\nu}\right)^{\theta}
$$

The constant $e_{0}$ and $e_{0}$ ' were used to account for initial differences in the lcading rates particularly between triaxial ccupression and triaxial extension tasts. The ritting stself his accorplished by the rethod of least squarea. $^{y, 15}$ It was also assumed thet the stress exponent in Equation (5) equalled three. ${ }^{10-14}$ The ritting parumeters according to 
Equations (1) through (3) are listed in Table VI. It is noted that the volumetric strains proved to be no more than 17 of the shear strains for the diration of the experifents. Therefore, setting $e \Rightarrow 0$ it foliowis that $e_{2}=e_{3} \approx-\frac{1}{2} e_{1}$, and $\gamma=\left(e_{1}-e_{3}\right) \approx \frac{3}{2} e_{x}$. The quantity $e_{x}$ is the axial sample strain. In compression $e_{x}=e_{1}$ and In extension $e_{x}=e_{3}$. The secondary creep estimates, constant $C_{4}=\dot{e}_{x}$ in Table $v$, conpare well with the smallest observed creep rates which were determined by means of linear leest square fits to the last, approximately 50 hours of test data for eech experiment (Table $v$ ). Future fits vilu deal directly with the experimentally monitored shear strains and volumetric strains after adàitional confirations of all measurements will fave been completed.

\section{D)scugsion}

The quasi-static data for West Hackberry salt are typical for rock salt from other sources. The salt behaves non-elastically even at low jeviator stress. This is Inticated by the small secant wosuli $E_{S} \leq \tilde{c} l x$ $1 C^{6}$ pai ( $14.6 \mathrm{GPa}$ ) in Table IV compared with a Young's modulus of $E \approx 5.15 \mathrm{x}$ $10^{6}$ psi ( $39 \mathrm{CFa}$ ). Pressure has a strong effect on the ultimate stresses ard strains over the range of confining pressures applied here, zero to 2000 pai (23.5 YFa). However, based or published data, the influence of pressure is bound to be greetest at $\sigma_{3} \leq 1500 \mathrm{ps} 1$ (10.3 $\mathrm{MPa}$ ) and decreases steacily es $\mathrm{J}_{3}$ is raised. For this reason, 1 t was expectel

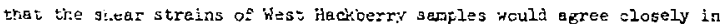
triaxial corpression and triaxial extension. In spite of the agreement in shear behavior, it is noted that systematis cifferences remeined in the volumetris strain response. If these results prove to : : orreat as is indlagted by the cross-checks of oll measurements, then the observed 


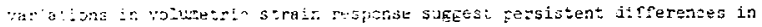

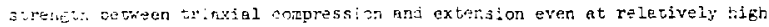
7. Iv test this poun, aritioral experibents shoull be carried out to

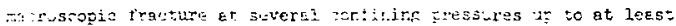
$1 ; .7: \%$.

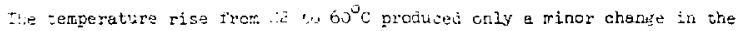

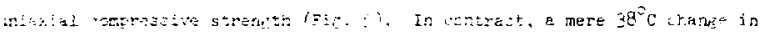

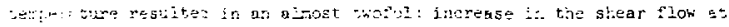

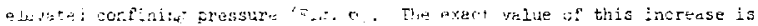

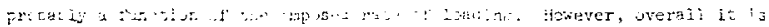

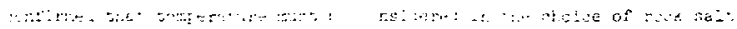

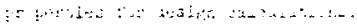

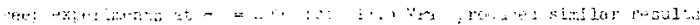

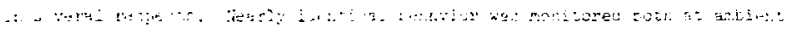

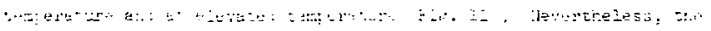

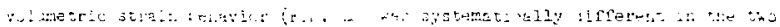

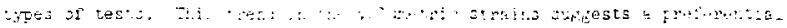

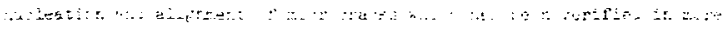

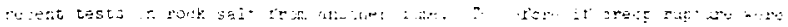

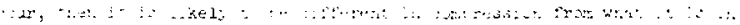
..:-nis;in.

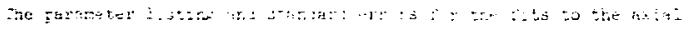

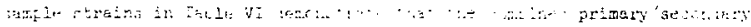

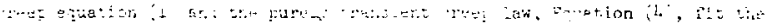

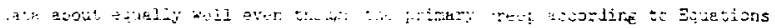

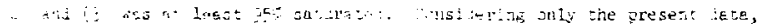

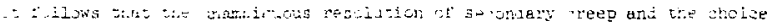


of the best creep law requires special tegta, including long-term ereep experisents. However, in the meantime, Equations (1) and (2) are favored on physical grounds and because it is likely that the ondsaton of secondary creep lesds to less conservative designa, i.e., smaller stralis, particularly if the design life is long.

Because sreep tests were carrled out only at one stress level, it was ixposaible to detemine the stress dependency of the creep of West Hackberry core. On the other hand, if the temperature dependence on secondary creep in Egliation ( 1 ) is described by the Heertman ${ }^{16}$ relation

$$
\dot{e}_{s}=A e^{-\theta / R T}\left(\frac{c_{1}-c_{3}}{\mu}\right)^{n}
$$

then the messurenents at 22 and $6 c^{\circ} \mathrm{C}$ yleld an activation energ $Q=11.4$ $\mathrm{kcal} /$ mole $(47.8 \mathrm{~kJ} / \mathrm{mole})$. $\mathrm{F}$ is che gas constant and $\mathrm{T}$ denotes absolute iemperature. If the temperature dependence in Equations (4) and (5) is contained in 3 either as

$$
\beta=\beta^{\prime} T^{3}
$$

or

$$
6=\beta^{n} e^{-U / R T}
$$

then she overage data at each test temperature implies $\mathrm{s}=9.32$ and $\mathrm{J}=5.6$ $\mathrm{kcBl} / \mathrm{xole}(23.4 \mathrm{~kJ} / \mathrm{mole})$.

It was one objective of this study to determine the comparative behavior of rocls selt from West Hackbery, Jefferson Island and from the Wellington formation at Lyons. The latter comparison automatically raises the added question whecher the properties of dome salt are different from those of 
bedled salt because of differences in tectonda hustories. Avalloble amient. tenpereture data frem all three sitec are sumarized In Table VII and tn Flgure 15. Several observatione are regdily apparent. The variation of the iltirate stresses, ultinete strains and sesant roduli upon irst laboratcry loading in Table VII are well within the typical data scetter for large suites of tests on rock salt from any location. ${ }^{17}$ The agreenent of data is perticulariy gend if $1 \mathrm{t}$ is considered thet the results vere obtained in different laboratories and on speciaens of different sizes. The only appsrent discropancy appears to exist in the matude of the intrinsic elestic corstants (colum 6 in Table VII). The post likeIy reason is a difference in mcasuremen: techniques and exfericental resolution. Fovever, it 1 s enphasized tinct the

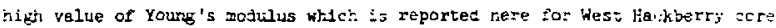
agrees perfectly with the Young's moduli which were computed from rock salt dersities ans from measured dilatational and shear wove velocities. ${ }^{16}$ The elastic constants in fable VII also ogree with those obtained for rock salt fron other 2ocations.

Figure 15 shows creep measurements to 20 hours which is the mekizu test duration for core from Jefferson is lana and iyous. The creep cursos for West Hackberry selt appear to be a good average for sine eight cirves from Jefferson Islond and Iyons. Although yll three sets of restilts diff't Iarkedly at srall tires, the average creep rates between 100 and 120 hours fall into the aerrow range from $\% .9 \times 10^{-9} \mathrm{I} / \mathrm{s}$ for Luons core to $2.24 \times 10^{-5} 1.5$ for Jefferson Island material. The average value for the ten tests shom in Figure 15 is $1.66 \times 10^{-8} 2 / s$. Civen the fict that the ereep rates between 100 and 120 hours Here overlapping, it becomes obvious to susgest that the lon tem response of materisi from al? three scurces is essentiplly the same. It appears further that the true differences in creep are limt ted to 
It.ble VII

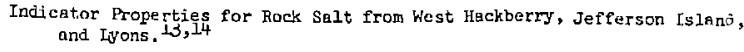

\begin{tabular}{|c|c|c|c|c|c|c|c|}
\hline $\begin{array}{l}\text { Material } \\
\text { Source } \\
\end{array}$ & $\begin{array}{r}\text { No. of } \\
\text { Tests or } \\
\text { Meagurerents } \\
\end{array}$ & $\begin{array}{c}o_{3} \\
(p s 1)\end{array}$ & $\begin{array}{l}\left(\sigma_{1}-\sigma_{3}\right) u \\
(\mathrm{psi})\end{array}$ & $\begin{array}{c}\text { Secant Mod; } E_{\mathrm{s}} \\
500 \leq \frac{\Delta q}{(\mathrm{psi})} \div 2000 \\
\left(10^{6} \mathrm{psi}\right)\end{array}$ & $\begin{array}{l}\text { Elastie } \\
\text { Constants } \\
E\left(10^{6} \text { pBi }\right) / v\end{array}$ & $\begin{array}{l}\left(e_{1}\right) \\
(\phi) \\
\end{array}$ & $\frac{\frac{d}{d t}\left(\sigma_{1}-\sigma_{3}\right)}{D_{B 1 / 0}}$ \\
\hline \multirow[t]{3}{*}{ West Hackberry } & 1 & 0 & 3780 & 0.67 & $\ldots$ & 2.5 & $i$ \\
\hline & 1 & 2000 & $>8570$ & 0.90 & -- & $>14.3$ & 1 \\
\hline & 6 & 0.2000 & --- & --- & $3.588_{-0.25}^{+0.33} / 0.37^{+0.03}-0.05$ & $\cdots$ & $>10$ \\
\hline \multirow[t]{5}{*}{ Jefferson Island } & 2 & 0 & $3120 \pm 15$ & $0.19 \pm 0.01$ & ---- & 2.9 & 0.3 \\
\hline & 1 & 0 & 3520 & 0.26 & ---- & 2.9 & 8.3 \\
\hline & 1 & 1500 & $>9650$ & 0.59 & $-\cdots$ & $>21.5$ & 8.3 \\
\hline & 2 & 2000 & $>6900$ & $0.39 \pm 0.06$ & $\cdots$ & $>13.5$ & 0.3 \\
\hline & 6 & $0-2000$ & ---- & --- & 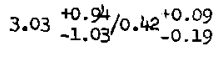 & $\cdots$ & -- \\
\hline \multirow[t]{4}{*}{ Lyons } & 3 & 0 & $3660+120$ & --" & $\cdots$ & $\leqslant 3.5$ & $\sim 2.5$ \\
\hline & 2 & 500 & $\cdots$ & $0.55 \pm 0.1$ & $\cdots$ & --- & $\sim 2.5$ \\
\hline & 7 & $500-5000$ & $m-$ & $>-.87 \pm \begin{array}{r}0.35 \\
-0.44\end{array}$ & $-\cdots$ & --- & -2.5 \\
\hline & 2 & $500-2000$ & $-\cdots-$ & $\cdots$ & $1.54 \pm 0.07 / \cdots$ & --- & $\sim 2.5$ \\
\hline
\end{tabular}


initisl creep response which is probab $2 y$ sensitive to varifions in recent stiple ristories in the sare way thet recent specimen histories are reflected

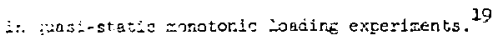

Te sirilarity setweer the rocte sait benavior in Figure 15 is not iint ted is jerferson Island, Lons and Nest Heckberry da:A. A comperison of hest Haskerry deta with the best fit to tests on becded salt from the Balado formation in Now Mexico, 9 provides excellent egreement. This is shown in Figure 16 where the secondary creep estimates for West lackoerry of Tebic vi

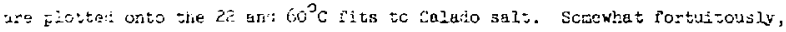

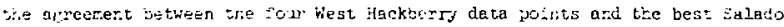
F'is is considerably pecter than the agreement between these fits and severol Enlvidual data points for Salado material whlch were ascertalned in anblent $\therefore$ mirgtire experimento (Fig. 16). This scatter in ctherwise cereful

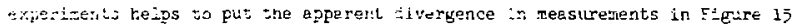
ato profer perspentive.

\section{Sumary and Conclusiona}

Six quasi-static ani four creep experiments on west Hackberry rock salt were described. All guasi-static test results, vitinate stresses anc strains, oldz: constaria and secent acduli curing first laboratory logdiafs, were 4.:- sinilar ic data for rolk salt from three other sourees. Pressure el'ects arn significant at low confining pressure. However, at $a_{3}=2$ zud pai (13.6 MPa) this efrect tias largely suppressed so that the snear behavior of West. Hackbery selt was almost identicel in triaxial compression and triaxial extenston. On the other hama, systematic differences in the volumetric strains ir. Lcate that the uli inate stresses and streins mint be different in the two cases 
1: such tegta are continued to fracture. A amall change in temperature from 22 to $60^{\circ} \mathrm{C}$ was, hown to produce subatant1al changea in the shear flow of hest Hiekticersy core.

Creep tests in triaxial compression and triaxtul extenston were anelyzed in Lerms of combined primary/secondary creep model and in terms of a pureiy trarsient formulation which was applfed 1n earlfer Hest Hackbarry analyses. 1 Both esclels described the experimental dota well for the duration of the present tests ( $t \leq 475$ hours). However, the combined primary/secondary interpretation we favored because it is consistent with some known flow recirenisms in haltte.

Almost identical shear creep data and aystematically varying voluretric creep results in compression and extension suggest that pressure does not irfluerce the flow of salt at $\sigma_{3}=2000 \mathrm{psi}(13.8 \mathrm{MPa}$ ) but that it might alter the development of creep rupture. Temperature had a very pronounced influence much like in quas1-8tatic tests. The comparison of creep data at 22 and $60^{\circ} \mathrm{C}$ inplies an activation energy of $\mathrm{Q}=11.4 \mathrm{hcal} / \mathrm{mole}(47.8 \mathrm{~kJ} / \mathrm{mole})$ for secondary creep and $U=5.6 \mathrm{keal} / \mathrm{mole}(23.4 \mathrm{~kJ} / \mathrm{mole})$ if creep is attributed solely to transient creep. If the temperature effect in the transient creep formulation is related to a power function of temperature, $T^{s}$ then $s=9.32$.

Neglecting early time data, the reaults for West Hackberry salt compare Well with creep data from the Jefferson Ialand dome and for bedded salt from =he iellington formation at Lyons, Kansas and from the Salado formation, southeastern New Mexico. The agreement is particularly good between secondary creep estlmated for West Hackberry and Salado material suggesting tha: isferent tectonic hiatories had no effeut. 
In view of the constatency of all results, it appears that little further mechaclcal vesting is needed on Weat Hackberry materlal unleas creep fructure is deened poseibie or unless particular structural, texturel or compositional anomalieg are encountered. Such anomalies might include cases where anhydite 18 concentrated primar1ly with sodium chloride orystals rether than along grein bounderies. It also appears that the tice depevidert rasponse of fies: Hackberry selt can be deseribed by mekns of exictine or evolving constitutive movela for Salado salt. 


\section{References}

1. Tilleraon, J. R. and P. D. Hilton, "Lork-Term Cavern Stability

Evaluatior," Appendix E In "Systems Integration and Engineering Support Study for the Strategic Petroleum Reserve (SFA) Program - Final Report," SFA Project D1v1aton 4702, ed., SALD79-0637, Send1a Viatlonal Laboratoriea, 1979.

2. Federal Energy Administration (now Department of Enerky), Strategic Fetroleum Reserve Office, Strategic Petroleum Aeserve - Pinal Environmental Impact Statement, Weat Hackberry Salt Dome, Fis $76 / 77^{-4}, 1977$.

3. $\exists i l d$, R. W., unpublished data, Sandia Satlonel Leboratorlea, 1980.

4. Bra1tocin, O., Salt Depogite - The1r Orig1n and Compogit1on, Springer-Verlag, 1971.

5. Wewersik, H. R., "Indirect Deformation (Strain) Measurements and Calibrations in Sandia Trlaxiel Apperatus for Rock Tegting to $250^{\circ} \mathrm{C}$," SAIN79-0114, Sendia National Laboratories, 1979.

6. PB/KBB, "Strategic Petroleum Reserve Progrem - Salt Dowe Geologr and Cavern Stabillty Analysis," Flnal Report to the Departwent of Enerey, August $197^{8}$.

7. Jacobs/D'Appolonia, "Thermal Analyseg, Stablllty Allalyaea and Recertification Requirements, Cavern \#6, Weat Hackberry S1te, Cameron Pariah, Louisiana," J/D-ROCb, Techn cal Direction \#J/D-17, 1979.

8. Herrmann, H., H. R. Wawersik and H. S. Iauson, "Creep Curves and F1tting Parameters for Southeastern New Mexics Becaded Salt, "SAFD80-0087, Sard1a Nitional Laboratoriea, 1980 .

9. Hermann, W., W. R. Wawergik and H. S. Ituson, "Analysis of stendy State Creep of Southeastern Hew Mexico Bedried Salt," SAND80-0558, Sandia Netionel Laboratortes, 1980.

10. Obert, L., "Deformational Behavior of kodel Pllara Made from Salt, Trona and Potash Ore," Proc. Sth U, S, Rock Kech. Symp., Univ, of fissour1, Rolla, Mo, 1964.

11. Lomenlck, T. F., "Laboratory Pillar Model Experiments," in "Project Salt Vault; A Demonstration of the Disposal of High Activity Solidified Hagtes in Underground Salt Mines," R. I. Bradsbaw and W. C. MeClasn, eds, , ORN-4555, Oak Ridge National Laborstory, 1971.

12. Dreyer, W., The Scterce of Roci Yechantce, Trens. Tech. Fublicatsons, 1972.

13. Hensen, F, D., "quesi-stet1c and Creep Deformation Characteristics of Bedded Selt fron the Carey Mine Near IJong, Kansas," Tech. Memor. Report RSI-0067, RE/SPEC, Inc., Rapid City, SD, 1978. 
4. Hengen, F. J., "Case Fistory Rock Wechanies Exarination of the Jefferson Island Salt Mine: I L Laborecory Bvaluation of Strength end Creep Deformation Characterlstics of Dame Salt Under Confining Pressure," Tech. Memor. Report RSI-0057, RE/SFEC, Inc., Rapld C1ty, SD, 1978 .

15. Jeffergon, T. H,, "TJaRl - A FORTRAN Subroutine for Nonlinear Lesst Jquares Feraneter Estivat1on," SLA73-0305, Sandia National iboratories, 1974 .

16. Weertan, J., "ilslocetion Clumb Theory of Steady-State Craep," Trans. AINE, 61, 1968 .

17. Dreyer, $N_{,}$, "Zur Druckfestigke1t von Salzgestelnea, "Kalł wid Stelnsalz, Heft $7,243-251,1961$.

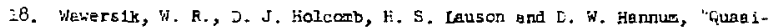
static apc Creep Lata for Done Salt from Eryan Nound, Texas," SAlnt60-143L, Gandia Netional Laboratories, 1980.

19. Wewergik, $W$, $R$. and $\mathrm{U}$. W. Hannum, "Mechanisal gehavior or Hev Nextco Rock Salt in Triaxial Compession to $200^{\circ} \mathrm{C}, " \mathrm{~J}$. Geophys. Res., B5, E., 2900 . 


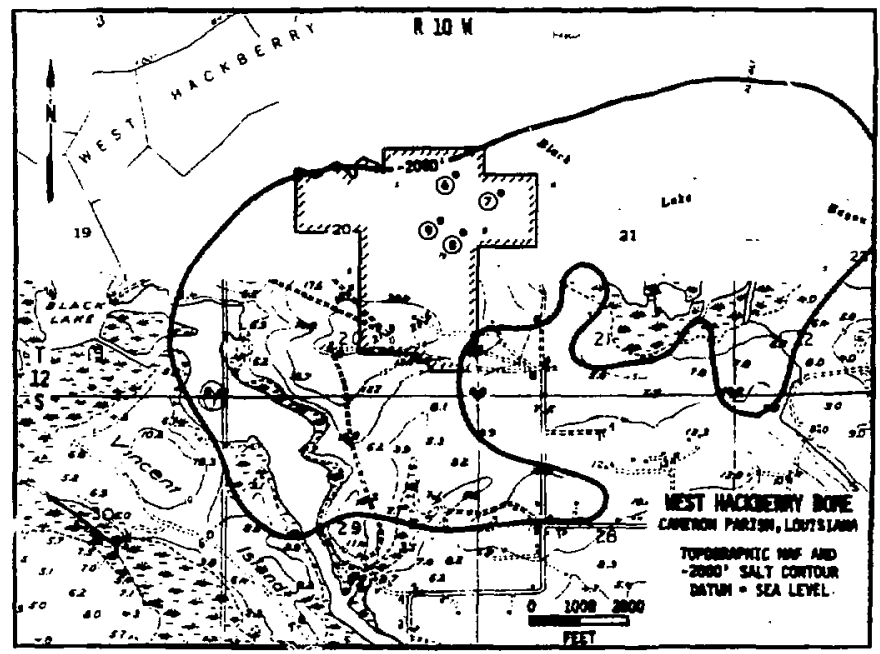

F1gure 1: Map of 2000 Pt $(625 \mathrm{~m})$ contour of Weat Hackberry dome. Crass hatched boundary dePines DOE property line. 


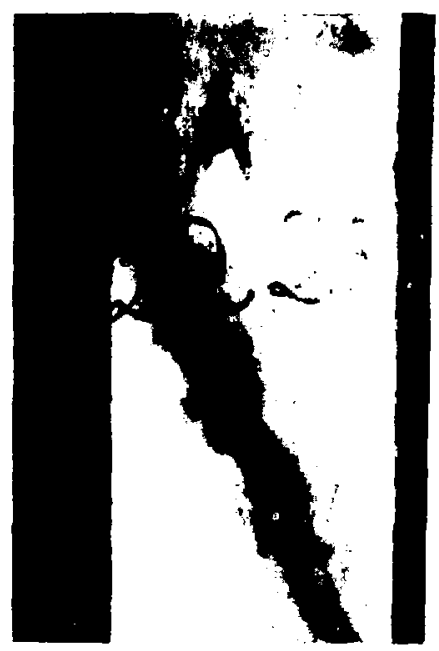

Figure 2: West Hackberry sample from drillhole \#6c depth $2223 \mathrm{ft}(695 \mathrm{~m})$ with back illumination. 


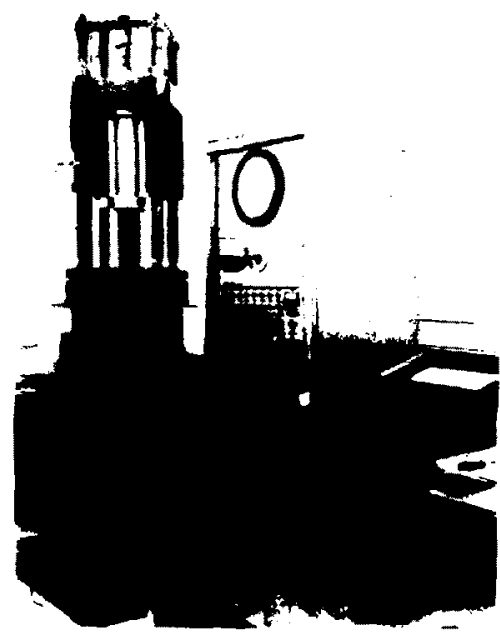

Figure 3: Triexial test apparaius.

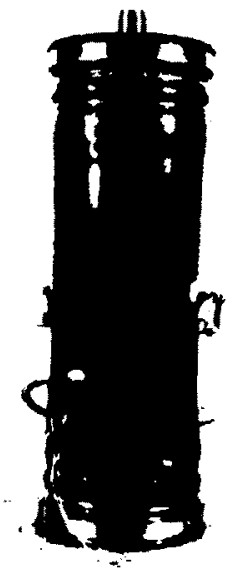

Figure if: Extet.3 ton specimen in flexible viton jacket with two disk gauges and iransfer buttons. 


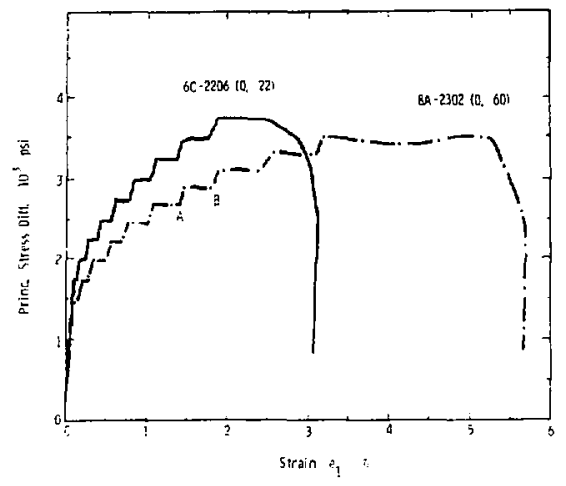

Figure 5: Principal otress difference vs. ax1al strain in unconfined compression tests $\mathrm{B}=22$ and $600 \mathrm{C}$.

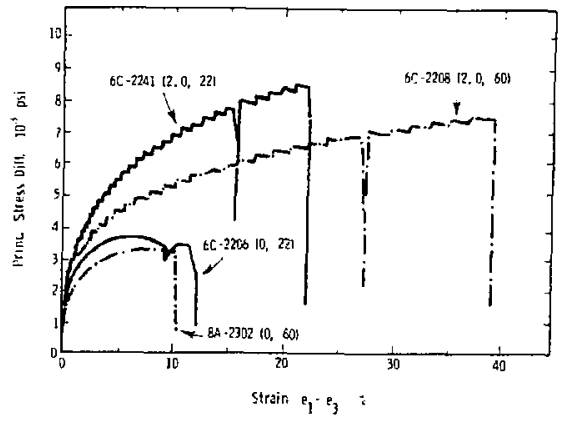

Flgure 6: Principal otregs difference vs, shegr strain for untaxtal and triaxlal compression tests $\left(\sigma_{2}=\sigma_{3}\right)$ at 22 and $60^{\circ} \mathrm{C}$. 


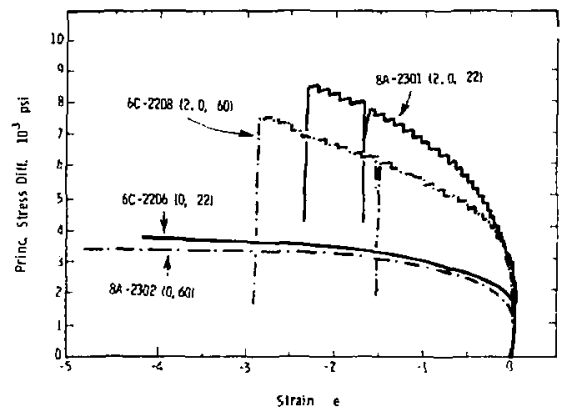

Figure 7: Princlpal stress diference va. volumetric strains for uniaxial and triaxial ccapression tests $\left(\sigma_{2}=J_{3}\right)$ at 22 and $60^{\circ} \mathrm{C}$.

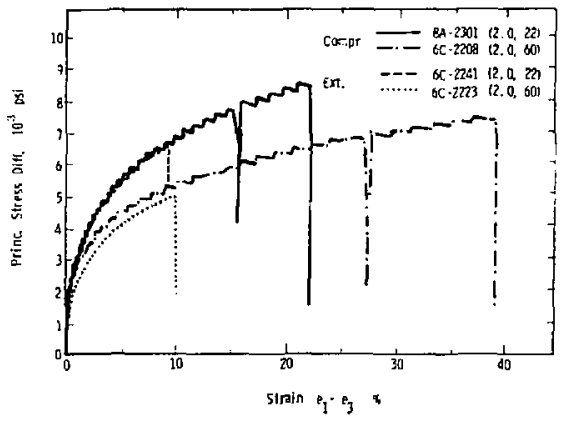

Figure 8; Comparison of triaxial compression and triaxial extension data in the space $\left(c_{1}-c_{3}\right)$ va. $Y=\left(e_{1}-e_{3}\right)$ at 22 and $60^{\circ} \mathrm{C}$. 


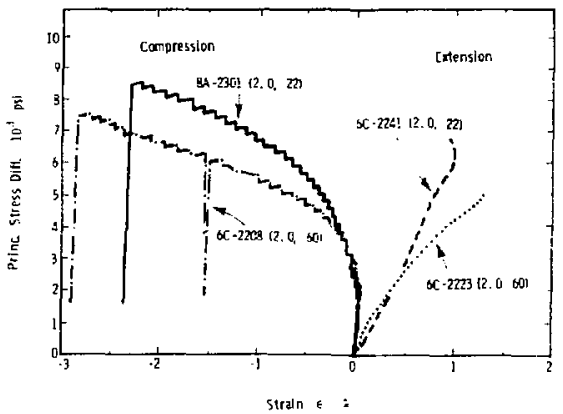

Figure 9: Comparison of triaxial compression and criaxial extension data 1r the space $\left(\sigma_{1}-\sigma_{3}\right)$ vs. e at 22 and $60^{\circ} \mathrm{C}$.

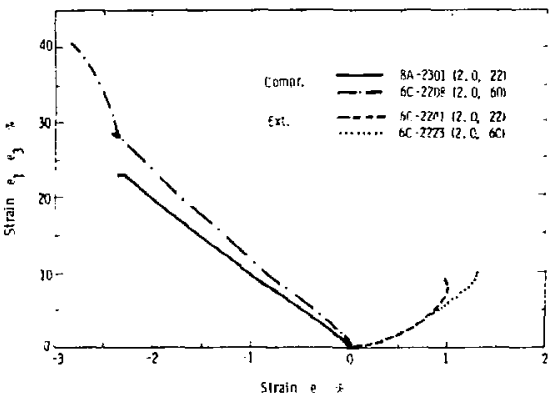

Flgure 1c: Comparison of triaxial compression and triaxial extension data in the space $r=\left(e_{1}-e_{3}\right)$ vs. e at 22 and $60^{\circ} \mathrm{C}$. 


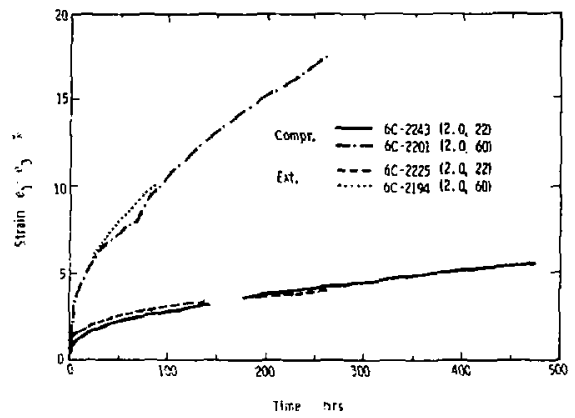

Figure 11: Shear creep in triaxial compreasion and triaxial extenston at 22 and $60^{\circ} \mathrm{C}$.

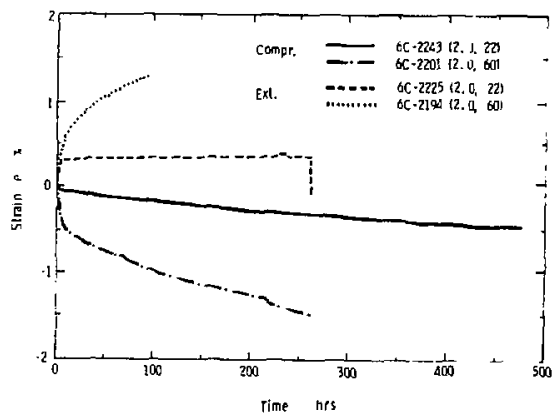

Figure 12: Volumetrie creep in triaxial compression and triaxial extension at 22 and $60^{\circ} \mathrm{C}$. 


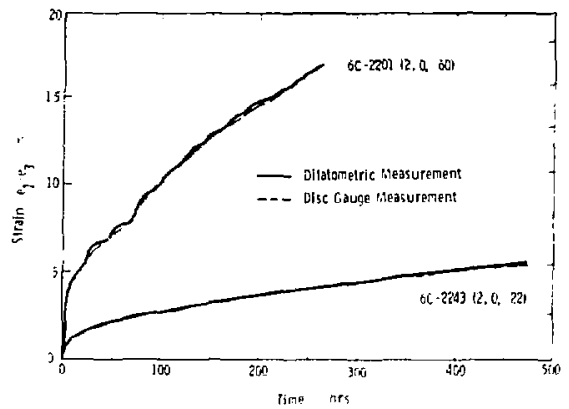

Fedre 13: Compartson of sheer creep based on independent messurezents of racial sasple deforctions.

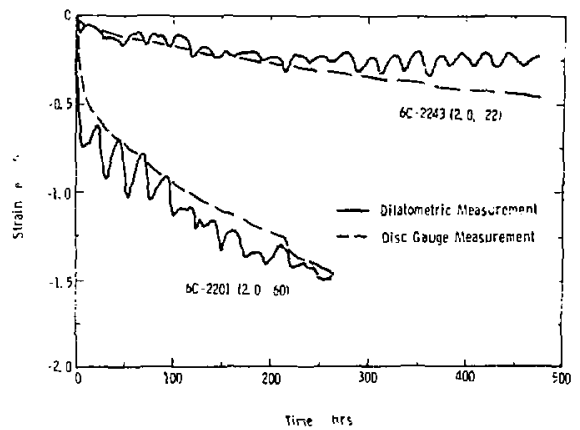

Figure 14: Comperieon of volinetric creep besed on 1ndependent measurecents of radial sample deformations. Nolse in ellatometric records is due to therally incuced rolume changes of confining pressure sediur. 


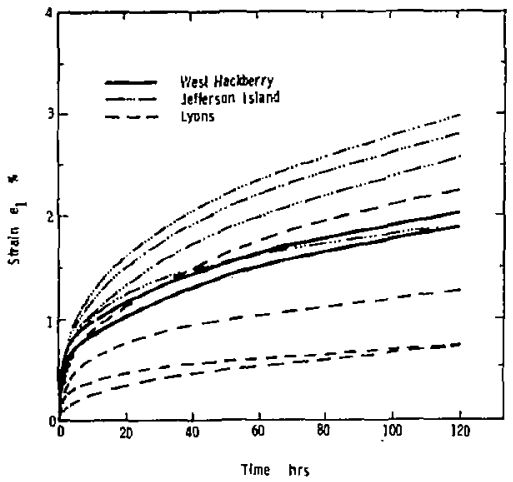

Figure 15: Comparlson of axial creep data, e, vs, $t$ for dome salt from West Hackberry and Jefferson Island, Ioutsiana and for bedded balt from Wellington formation, Luone, Kansag. $\left(a_{1}-a_{3}\right)=3000$ psi, $500 \leqq a_{3} 5$ 2000 psi.

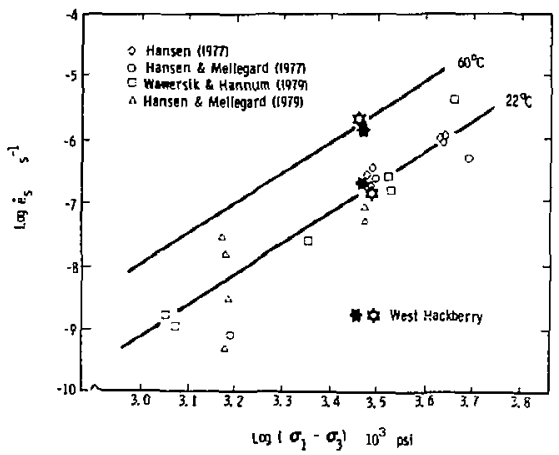

Figure 16: Comparison of secondary (ateady atete) ereep rateg for West Hackberry cone salt w1 th tedded salt from the Salado Iormation, southeastern New Mexico. 